\title{
Article \\ Detection of Microorganisms in Body Fluids via MTT-PMS Assay
}

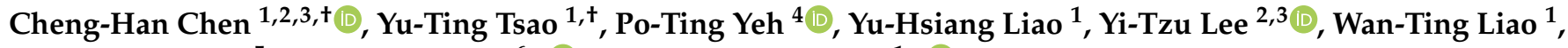 \\ Yung-Chih Wang ${ }^{5}$, Ching-Fen Shen ${ }^{6, *(D)}$ and Chao-Min Cheng $1, *$ (D)
}

check for updates

Citation: Chen, C.-H.; Tsao, Y.-T.; Yeh, P.-T.; Liao, Y.-H.; Lee, Y.-T.; Liao, W.-T.; Wang, Y.-C.; Shen, C.-F.; Cheng, C.-M. Detection of Microorganisms in Body Fluids via MTT-PMS Assay. Diagnostics 2022, 12, 46. https://doi.org/10.3390/ diagnostics 12010046

Academic Editor: Liselotte Hardy

Received: 20 November 2021

Accepted: 23 December 2021

Published: 27 December 2021

Publisher's Note: MDPI stays neutral with regard to jurisdictional claims in published maps and institutional affiliations.

Copyright: (C) 2021 by the authors. Licensee MDPI, Basel, Switzerland. This article is an open access article distributed under the terms and conditions of the Creative Commons Attribution (CC BY) license (https:// creativecommons.org/licenses/by/ $4.0 /)$.
1 Institute of Biomedical Engineering, National Tsing Hua University, Hsinchu 30013, Taiwan; gdc123.tw@gmail.com (C.-H.C.); sherry450047@gmail.com (Y.-T.T.); a29248510@hotmail.com (Y.-H.L.); u104015025@cmu.edu.tw (W.-T.L.)

2 Department of Emergency Medicine, Taipei Veterans General Hospital, Taipei 11217, Taiwan; s851009@yahoo.com.tw

3 School of Medicine, National Yang Ming Chiao Tung University, Taipei 11221, Taiwan

4 Department of Ophthalmology, National Taiwan University Hospital, Taipei 10002, Taiwan; ptyeh67@gmail.com

5 National Defense Medical Center, Division of Infectious Diseases and Tropical Medicine, Department of Internal Medicine, Tri-Service General Hospital, Taipei 11490, Taiwan; wysywyst@gmail.com

6 Department of Pediatrics, National Cheng Kung University Hospital, College of Medicine, National Cheng Kung University, Tainan 70101, Taiwan

* Correspondence: drshen1112@gmail.com (C.-F.S.); chaomin@mx.nthu.edu.tw (C.-M.C.)

+ These authors contributed equally to this work.

\begin{abstract}
Early detection of microorganisms is essential for the management of infectious diseases. However, this is challenging, as traditional culture methods are labor-intensive and time-consuming. The 3-(4,5-dimethylthiazol-2-yl)-2,5-diphenyltetrazolium bromide-phenazine methosulfate (MTTPMS) assay has been used to evaluate the metabolic activity in live cells and can thus be used for detecting living microorganisms. With the addition of $\mathrm{NaOH}$ and Tris-EDTA, the same approach can be accelerated (within $15 \mathrm{~min}$ ) and used for the quick detection of common bacterial pathogens. The assay results can be evaluated colorimetrically or semi-quantitatively. Here, the quick detection by MTT-PMS assay was further investigated. The assay had a detection limit of approximately $10^{4} \mathrm{CFU} / \mathrm{mL}$. In clinical evaluations, we used the MTT-PMS assay to detect clinical samples and bacteriuria ( $>10^{5} \mathrm{CFU} / \mathrm{mL}$ ). The negative predictive value of the MTT-PMS assay for determining bacteriuria was $79.59 \%$ but was $100 \%$ when the interference of abnormal blood was excluded. Thus, the MTT-PMS assay might be a potential "rule-out" tool for bacterial detection in clinical samples, at a cost of approximately USD 1 per test. Owing to its low cost, rapid results, and easy-to-use characteristics, the MTT-PMS assay may be a potential tool for microorganism detection.
\end{abstract}

Keywords: MTT-PMS assay; bacterial detection; point-of-care testing; infectious diseases; human body fluids

\section{Introduction}

Infectious diseases remain a major cause of ill health and socioeconomic burden in contemporary healthcare systems [1]. In 2017, 48.9 million cases of sepsis and 11 million sepsis-related deaths were reported worldwide [1]. According to the World Health Organization, infectious diseases are responsible for $54.4 \%$ of all global deaths. In particular, developing areas with low healthcare accessibility, such as Africa and Latin America, exhibit high incidence of infectious diseases and related mortality [1,2]. Despite developments in modern medicine, there are over 100,000 deaths attributed annually to infectious diseases in the United States [3]. Mortality risk from severe infection, or sepsis, increases by $7.6 \%$ for every hour of delayed antibiotic treatment; yet misuse or overuse of broad-spectrum 
empirical antibiotics leads to high rates of antimicrobial resistance [4,5]. By 2050, antimicrobial resistance-related mortality is estimated to increase to 10 million deaths per year, an outcome that will increase individual and communal economic burdens [5]. Furthermore, diagnostic delays and inaccuracies make patients more vulnerable to severe complications [6-9]. To effectively treat or manage infectious diseases, it is crucial to develop a tool for the early and precise determination of causal pathogens [2].

The process of infectious pathogen identification is comprising three main steps, i.e., pathogen detection, identification, and antimicrobial susceptibility testing [10]. When using conventional methods for pathogen identification, the results of incubation, culture, and staining are usually not available until $24 \mathrm{~h}$ after sample collection [5,11,12]. Microorganism culture, the long-term gold standard technique for microorganism identification, is labor-intensive and time-consuming [4,5]. These techniques have been widely utilized for microorganism detection since the 19th century [12-14], but they require at least 1-3 days for the initial incubation and approximately 1 week to provide confirmed antimicrobial susceptibility testing results $[12,15]$.

Recently, biotechnological approaches have been introduced to accelerate the process of pathogen identification, including polymerase chain reaction (PCR) amplification, matrixassisted laser desorption ionization time-of-flight (MALDI-TOF) spectrometry, and enzymelinked immunosorbent assays (ELISA) [16-19]. However, these methods require highly qualified personnel and expensive equipment [16]. These disadvantages impede the implementation of these biotechniques in developing countries where infectious diseases continuously threaten and burden healthcare systems. Simple and inexpensive pathogen detection methods should be developed for resource-limited areas [20-22]. A simple and easy-to-use screening tool for the early detection of the presence of a pathogen is warranted.

Point-of-care testing (POCT), an emerging healthcare system, is specifically designed as a portable, rapid, and easily accessible approach for providing patients and healthcare personnel with immediate results. Various POCT techniques, focused on early bacterial detection, identification, or antimicrobial susceptibility testing, can be used for sepsis care $[10,23]$. Thus, POCT expedites clinical decisions and facilitates pathogen-targeted disease monitoring and management. To facilitate sepsis management, POCT can be divided into two categories, i.e., pathogen information acquisition and host monitoring. Pathogen acquisition consists of three parts, i.e., pathogen detection, pathogen identification, and antibiotic susceptibility testing [10]. With this approach, diseases can be diagnosed at an early stage, resulting in improved outcomes for patients by triaging infectious patients and accelerating treatment $[24,25]$.

The 3-(4,5-dimethylthiazol-2-yl)-2,5-diphenyltetrazolium bromide-phenazine methosulfate (MTT-PMS) assay is a colorimetric technique that has been previously used to evaluate the metabolic activity of live cells [26]. In this approach, the lightly-colored tetrazolium salt is enzymatically reduced to its intensely purple-blue formazan form (Figure 1). The tetrazolium reduction reaction is associated with the electron transport system of viable microorganisms [26]. Although the mechanism of reduction of MTT in bacteria remains unknown, the quantity of reduced formazan is proportional to the number of viable bacteria in the test solution [26,27]. This reaction can be monitored spectrophotometrically, providing a semi-quantitative readout indicating the presence of microorganisms [26]. The traditional MTT assay usually requires several hours of processing time. The MTT-PMS assay is performed using an intermediate electron acceptor, PMS, which accelerates the reaction allowing for a turnaround time of under $45 \mathrm{~min}[28,29]$. Our previous studies have demonstrated that the MTT-PMS assay can provide a rapid and semi-quantitative result of bacterial detection in water [16]. With the addition of Tris-EDTA (Tris-Ethylenediaminetetraacetic acid) and sodium hydroxide, the presence of bacteria in water was successfully detected within $15 \mathrm{~min}$ [16]. The quick turn-around time for this test lends to the potential application of the MTT-PMS assay for detecting the presence of bacteria in clinical human body fluids and as a POCT platform to screen for pathogen presence. However, to the best of our knowledge, the efficacy of the MTT-PMS assay in clinical samples for bacterial detection 
remains unknown. Therefore, this study was designed to evaluate the effectiveness of the MTT-PMS assay for bacterial screening in a range of solutions from phosphate-buffered saline to clinical human body fluid samples.

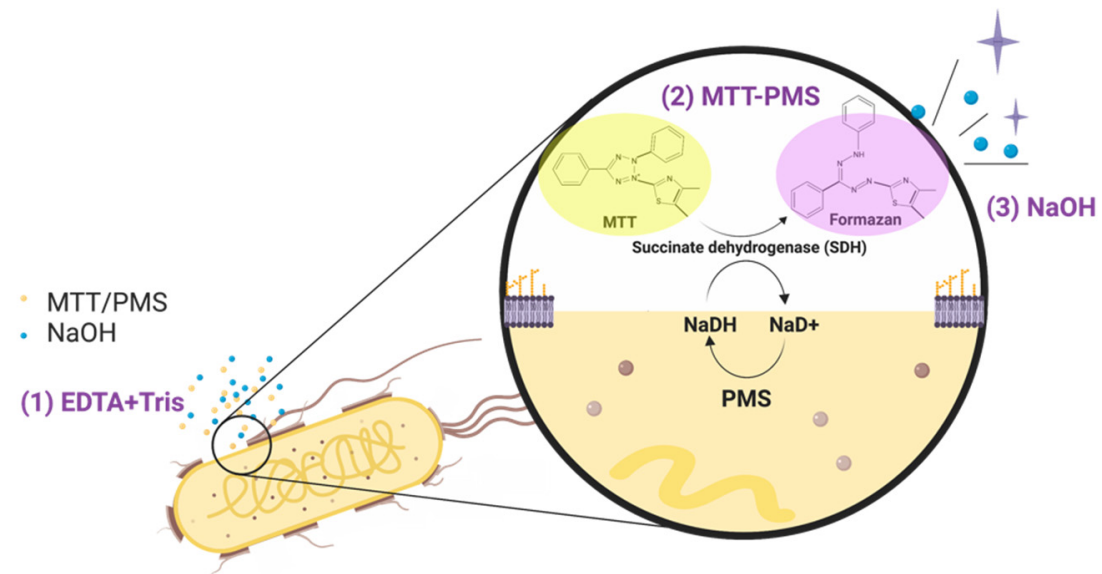

Figure 1. Mechanism of the 3-(4,5-dimethylthiazol-2-yl)-2,5-diphenyltetrazolium bromide-phenazine methosulfate (MTT-PMS) assay: (1) Tris/EDTA solution was used to penetrate bacterial cell walls and MTT/PMS was allowed to react with cellular succinate dehydrogenase; (2) MTT-PMS and NaOH were added to the solution. The lightly-colored tetrazolium salt was reduced to an intensely purple formazan form; (3) $\mathrm{NaOH}$ stimulated and amplified the reaction. The entire process was completed within $15 \mathrm{~min}$. The figure was created using BioRender.com.

\section{Materials and Methods}

\subsection{Study Design}

In this study we conducted MTT-PMS assays using three different conditions. First, to evaluate the detection efficacy and accuracy, we conducted the assays using varied concentrations of bacteria in PBS. Second, we simulated plasma conditions using intraocular fluid; a transparent, watery, plasma-like fluid with low protein concentration and few blood cells. We compared the results of the MTT-PMS assay with intraocular fluid to results from intraocular culturing tests from samples collected at National Taiwan University Hospital (a tertiary hospital with 2400 beds in Taiwan). Because of the blood-ocular barrier, intraocular samples present an uncomplicated background for bacterial detection in human body fluids [30]. Finally, we conducted MTT-PMS assays for bacteriuria detection in clinical urine samples collected from Taipei Veteran General Hospital (TVGH, a tertiary hospital with 2700 beds in Taiwan) and compared the results with those of routine urinary culture. Human urine samples are complex fluids with varying concentrations of inorganic salts and organic compounds, including hormones, proteins, and a wide range of metabolites [30]. The image-recording system used included a Tecan Sunrise ${ }^{\mathrm{TM}}$ Absorbance Microplate Reader (8708 Männedorf, Switzerland: Tecan) and an iPhone XS (Cupertino, CA, USA: Apple inc.). ImageJ software [31] was used for the image analysis. Furthermore, Staphylococcus aureus (TL341), Escherichia coli (DH5 $\alpha$ ), Klebsiella pneumoniae (ATCC 23357), and Pseudomonas aeruginosa (PA01) were used as target bacteria in this study. Bacterial viability was calculated using the following equation:

CFU (colony-forming units) $/ \mathrm{mL}=($ number of colonies $\times$ dilution factor $) \times 10$

More details regarding the reagents, equipment, and bacterial preparation are provided in the Supplementary Materials.

\subsection{Reagents and Protocol Development}

The MTT-PMS solution was prepared by adding $5 \mathrm{mg} / \mathrm{mL}$ MTT to $0.2 \mathrm{mg} / \mathrm{mL}$ PMS. The Tris/EDTA solution ( $\mathrm{pH}$ 8.0) was prepared by diluting Tris-EDTA buffer to a concentra- 
tion of 10-7 M EDTA with $0.1 \mathrm{mM}$ Tris buffer. Tris/EDTA solution (30 $\mu \mathrm{L})$ was added to a $30 \mu \mathrm{L}$ urine sample and incubated at $25^{\circ} \mathrm{C}$ for $5 \mathrm{~min}$ before adding $30 \mu \mathrm{L}$ of the MTT-PMS solution, followed by the addition of $2 \mu \mathrm{L}$ of $\mathrm{NaOH}$. Colorimetric detection was performed at $595 \mathrm{~nm}$ using a plate reader. Tris/EDTA solution was used to break down bacterial cell walls and allow MTT-PMS to react with cellular succinate dehydrogenase. Succinate dehydrogenase transformed the yellow-colored MTT into purple formazan. PMS facilitated this reaction as an intermediate electron acceptor. In the last step, $\mathrm{NaOH}(0.1 \mathrm{~N})$ was used to adjust the $\mathrm{pH}$ to amplify the colorimetric signal.

\subsection{Patient Selection}

\subsubsection{Intraocular Fluid}

After obtaining approval from the Institutional Review Board (IRB) of the National Taiwan University Hospital (IRB number 1083707256), we obtained intraocular fluid samples from patients diagnosed with endophthalmitis just before their intravitreal antibiotic injection therapy. This study was conducted following all relevant guidelines and tenets of the Declaration of Helsinki. All patients recruited in this study provided written informed consent before enrollment. A 27-gauge needle was used to collect the intraocular fluid and the samples were immediately stored at $4{ }^{\circ} \mathrm{C}$ until further analysis.

\subsubsection{Urine Sample}

After approval from the IRB of TVGH (IRB, TPEVGH 2019-10-001B), we obtained urine samples from patients admitted to the emergency department who were suspected of having a urinary tract infection (UTI). This study was conducted following all relevant guidelines and tenets of the Declaration of Helsinki. All patients recruited in this study provided written informed consent before enrollment. Routine examination of the urine samples was performed, and the samples were divided into three aliquots. One aliquot was checked with a urinary dipstick (MEDITAPE ${ }^{\mathrm{TM}}$ UC-11A. Kobe, Japan: Sysmex Corp.) at TVGH. Another aliquot was sent to the TVGH Central Lab for routine urinary culture, the gold standard test (incubation at $37^{\circ} \mathrm{C}$ for $24 \mathrm{~h}$ ) with a positive test cutoff value of $10^{5} \mathrm{CFU} / \mathrm{mL}$. The third aliquot was immediately stored at $4{ }^{\circ} \mathrm{C}$ and sent to the laboratory for further analysis.

\subsection{Statistical Analysis}

All MTT-PMS assay results are expressed as CFU / mL. For the microplate reader-based protocol, the optical intensity results measured by the microplate reader were expressed as the mean \pm standard deviation. For the smartphone camera-based protocol, the images were converted into grayscale using ImageJ software with the formula:

$$
\text { gray }=(\text { red }+ \text { green }+ \text { blue }) / 3 \text {. }
$$

Comparisons of the mean intensity between different bacterial concentrations were analyzed using the Student's $t$-test for normally distributed data or the Mann-Whitney U-test for non-normally distributed data. The intra-assay coefficients of variability for the MTTPMS assay were calculated by dividing the standard deviation of the blank value by the mean of the blank value and multiplying by 100 . For all statistical results, a $p$-value $<0.05$ was considered statistically significant. All statistical analyses were performed using IBM SPSS Statistics for Windows (version 22.0. Armonk, NY, USA: IBM Corp.).

\section{Results}

\subsection{Development of MTT-PMS Bacterial Detection Assay}

The sequential color changes at the different stages of the MTT-PMS assay are illustrated in Figure 2. To clearly demonstrate the colorimetric response, the volume of the reagents used in the experiments shown in Figure 2 were 10-fold higher than that typically used for the microplate protocol but were the same volumes which are used in 
the smartphone-based protocol. After precipitation of the purple-colored formazan with $\mathrm{NaOH}$, the final brown/dark green solution was formed by mixing yellow PMS and purple formazan. The final colorimetric output was captured $5 \mathrm{~min}$ after the final reagent was added.
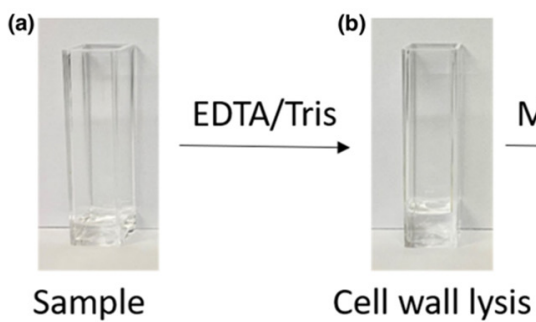

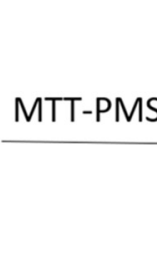

Bacterial viability detection

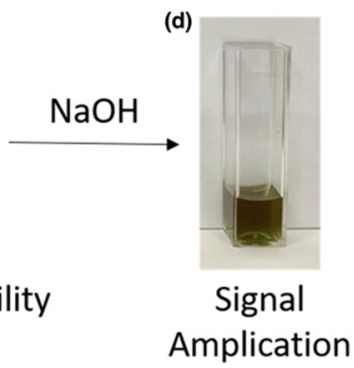

Figure 2. Sequential color changes associated with the 3-(4,5-dimethylthiazol-2-yl)-2,5-diphenyltetrazolium bromide-phenazine methosulfate (MTT-PMS) assay: (a) Bacterial samples were prepared using a buffer system; (b) EDTA/Tris was added for cell wall lysis. (c) MTT-PMS was added to the solution. The lightlycolored tetrazolium salt was reduced to an intensely purple formazan form. (d) $\mathrm{NaOH}$ was added for reaction amplification.

The effectiveness of each reagent was tested, and the results are shown in Figure 3 . The colorimetric differences between low and high bacterial concentrations were evident when all three reagents, namely, MTT-PMS, Tris/EDTA, and $\mathrm{NaOH}$ solution, were added. All reagents were used in subsequent experiments. The optimized protocol recorded dynamic colorimetric results at $595 \mathrm{~nm}$. The results indicated that the MTT-PMS biochemical reaction tended to remain stable after approximately $300 \mathrm{~s}$ (Figure 3b). Accordingly, we recorded all subsequent colorimetric results after $5 \mathrm{~min}$ of incubation. The method for establishing the standard curves is described in the Supplementary Materials.

(a)

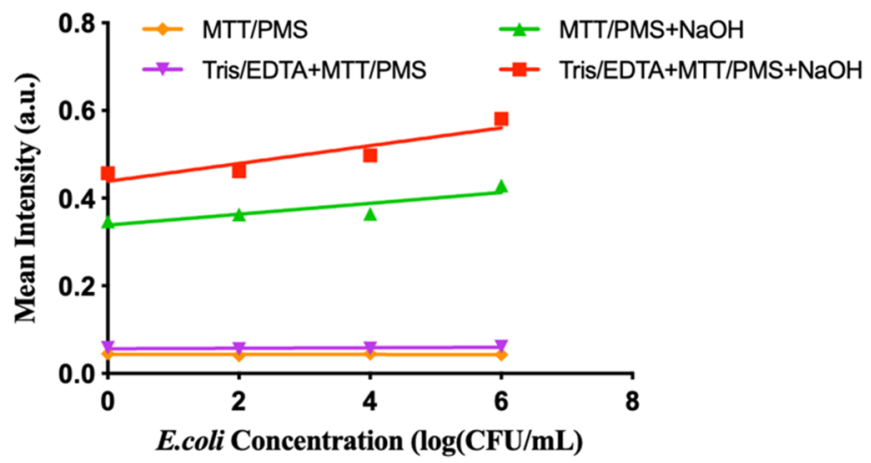

(b)

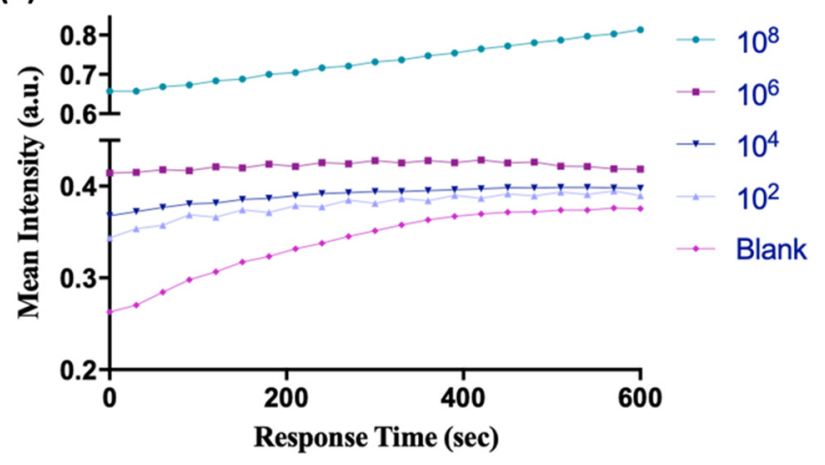

Figure 3. Establishment of the 3-(4,5-dimethylthiazol-2-yl)-2,5-diphenyltetrazolium bromidephenazine methosulfate (MTT-PMS) bacterial detection assay protocol: (a) Functional validation of each reagent: The colorimetric results of MTT-PMS and Tris/EDTA + MTT-PMS assays demonstrated no differences in bacterial concentration at $5 \mathrm{~min}$ (purple and orange lines). In the group treated with MTT-PMS $+\mathrm{NaOH}$, a semi-quantitative colorimetric signal was observed at 5 min (green line). With the addition of Tris-EDTA + MTT-PMS + NaOH, the quantitative colorimetric response became visible (red line). The slope of the green line is 1.6-fold higher than that of the blue line (0.02 vs. 0.012); (b) Dynamic colorimetric results of the MTT-PMS assay at $595 \mathrm{~nm}$. Signals were recorded every $20 \mathrm{~s}$ for $10 \mathrm{~min}$.

We used the MTT-PMS assay to detect S. aureus, E. coli, P. aeruginosa, and K. pneumoniae in a buffer system. The results are shown in Figure 4 . The MTT-PMS assay demonstrated the ability to detect all four bacterial species in the blank, up to a concentration of $10^{8} \mathrm{CFU} / \mathrm{mL}$. The results were obtained using a microplate reader at $595 \mathrm{~nm}$ with methods calibrated 
for bacterial viability of each individual species of bacteria. The results of the spread plate method were compared with those of the MTT-PMS assay, and this is shown in Figure 4. Figure $4 \mathrm{e}$ shows the limit of detection and limit of quantification of the MTT-PMS assay for different species calculated using Hill's equation. The applicability of the MTT-PMS assay to a smartphone camera-based protocol was also assessed using S. aureus and E. coli as Grampositive and Gram-negative species, respectively. The results are shown in Figure 5. Using the smartphone camera-based protocol, the MTT-PMS assay successfully distinguished bacterial concentrations below $10^{4} \mathrm{CFU} / \mathrm{mL}$ and above $10^{6} \mathrm{CFU} / \mathrm{mL}$, calculated using Hill's equation.

(a)

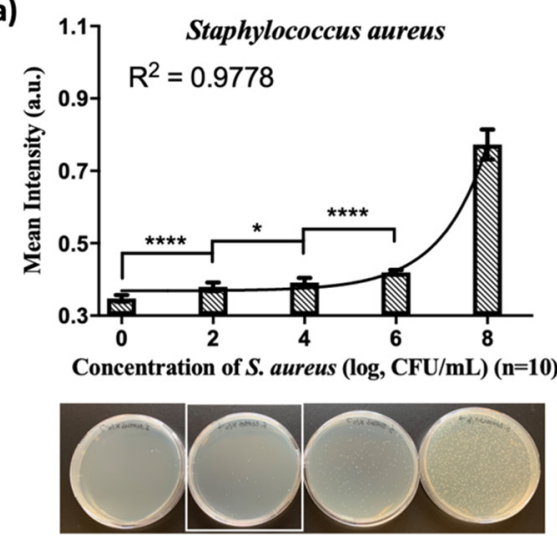

(c)

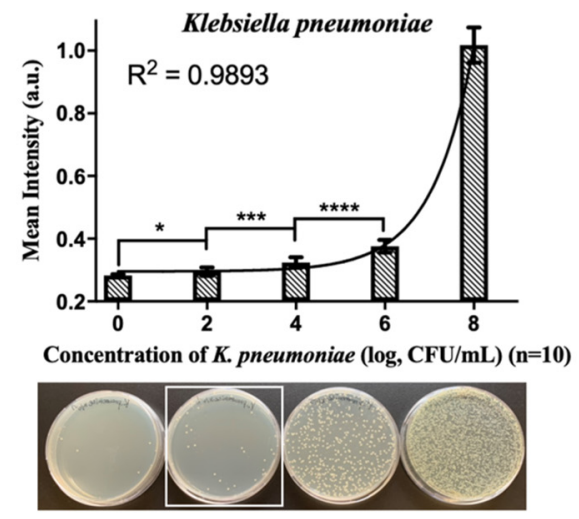

(b)

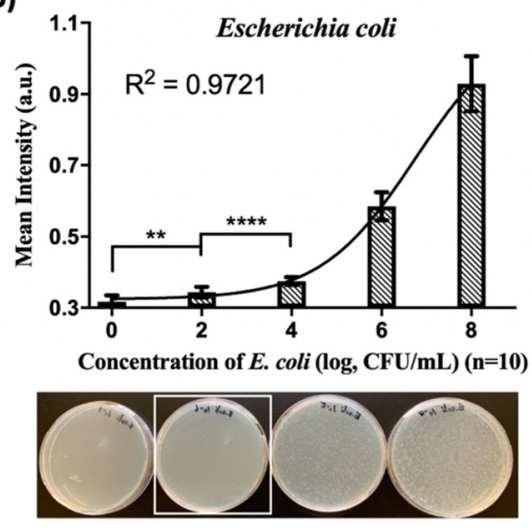

(d)

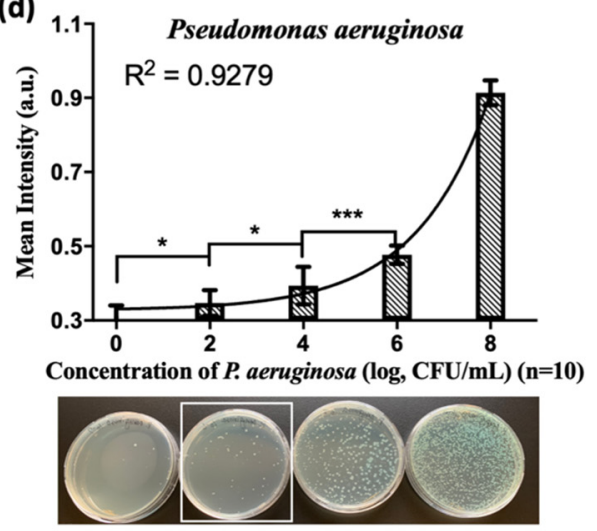

(e)

\begin{tabular}{|l|l|l|}
\hline & LOD & LOQ \\
\hline S. aureus & $10^{5.3}$ & $10^{6.5}$ \\
\hline E. coli & $10^{4}$ & $10^{5.5}$ \\
\hline K. pneumoniae & $10^{4.2}$ & $10^{5.3}$ \\
\hline P. aeruginosa & $10^{4.2}$ & $10^{6}$ \\
\hline
\end{tabular}

Figure 4. Detection capacity of the 3-(4,5-dimethylthiazol-2-yl)-2,5-diphenyltetrazolium bromidephenazine methosulfate (MTT-PMS) assay for different bacterial species. The results were recorded using a microplate reader at $595 \mathrm{~nm}$, and all experiments were repeated 10 times to ensure efficacy and reproducibility. Results of the MTT-PMS assay for: (a) S. aureus; (b) E. coli; (c) K. pneumoniae, and (d) P. aeruginosa. All assays demonstrated significant differences among the different bacterial concentrations. $\left({ }^{*} p<0.05,{ }^{* *} p<0.01,{ }^{* * *} p<0.001,{ }^{* * * *} p<0.0001\right.$ ); (e) Limit of detection (LOD) and limit of quantification (LOQ) of the MTT-PMS assay in a buffer system for different species as calculated using Hill's equation). 
(a)
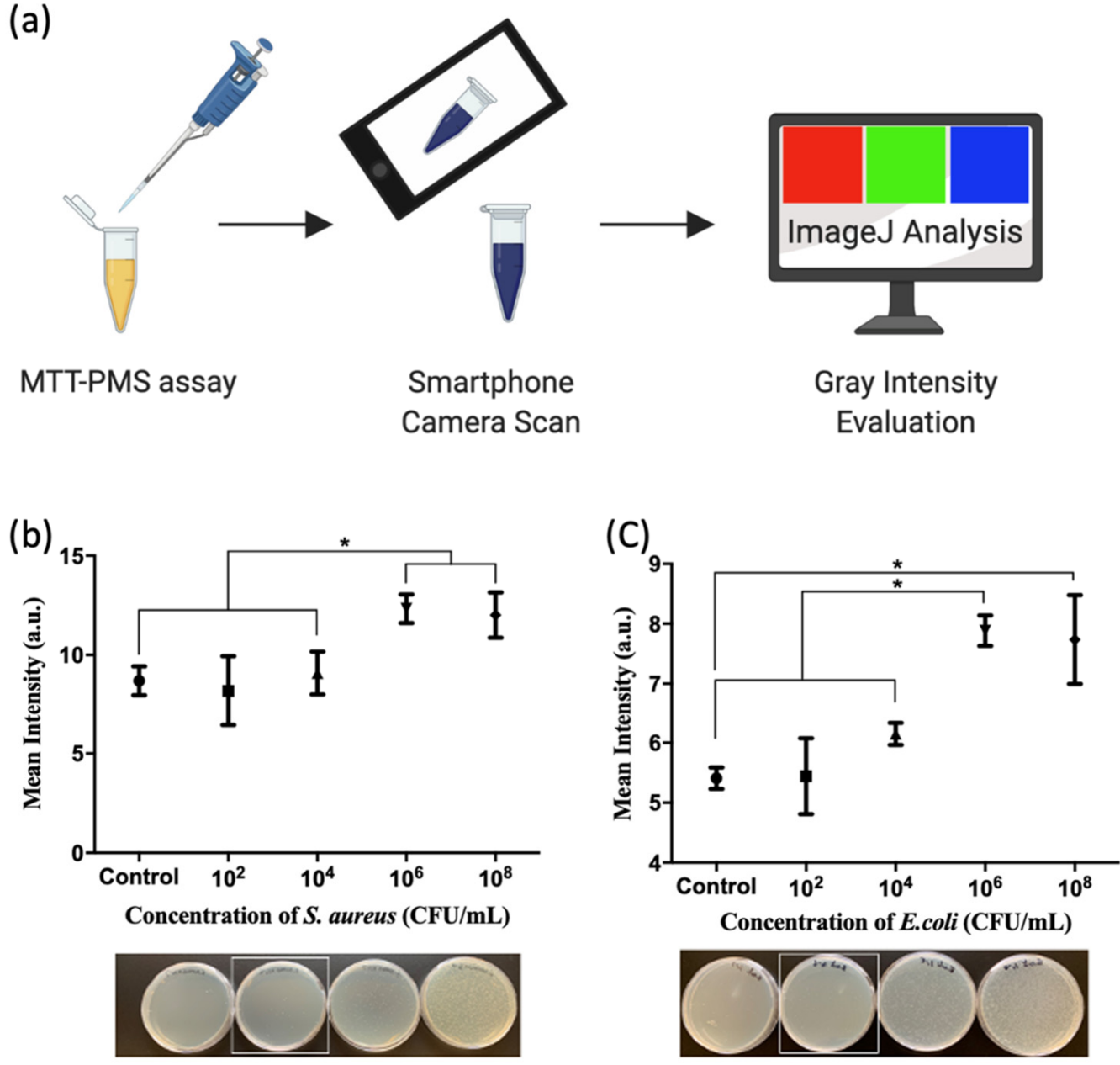

Figure 5. Integration of the 3-(4,5-dimethylthiazol-2-yl)-2,5-diphenyltetrazolium bromide-phenazine methosulfate (MTT-PMS) assay with a smartphone camera: (a) After adding MTT-PMS to the experimental tube, results were scanned with a smartphone (iPhone XS, Apple). The gray intensity was evaluated using a freeware App "ImageJ"[31]; Results of the MTT-PMS assay for (b) S. aureus and (c) E. coli. Figure created in BioRender.com. ${ }^{*} p<0.05$.

\subsection{Clinical Evaluation of MTT-PMS Assay for Living Microorganism Detection \\ 3.2.1. MTT-PMS Assay of Human Intraocular Fluid}

Six patients diagnosed with endophthalmitis were enrolled in this study. Group 1 comprised five samples obtained before the patients received any treatment. Group 2 comprised one sample obtained from the remaining patient after the administration of an intra-vitreous antibiotic injection. Of the six patients, five were diagnosed with exogenous endophthalmitis and one was diagnosed with endophthalmitis. Three aqueous humor samples and three vitreous humor samples were acquired. The final diagnosis was confirmed using a hospital report by combining clinical findings (symptoms, signs, and response to antibiotics) and bacterial culture reports. The basic characteristics of the six samples are listed in Table 1. 
Table 1. Characteristics of patients with endophthalmitis and their test results.

\begin{tabular}{|c|c|c|c|c|c|c|c|c|c|}
\hline & No. & Age & Sex & Eye Site & $\begin{array}{c}\text { Disease } \\
\text { Diagnosis }\end{array}$ & $\begin{array}{l}\text { Underlying } \\
\text { Disease }\end{array}$ & $\begin{array}{l}\text { Sample } \\
\text { Type }\end{array}$ & Culture Result & $\begin{array}{c}\text { MTT-PMS } \\
\text { Assay Results }\end{array}$ \\
\hline \multirow{5}{*}{ Group 1} & 1 & 62 & $\mathrm{~F}$ & $\mathrm{OD} *$ & $\begin{array}{l}\text { Endophthalmitis } \\
\text { (exogenous) }\end{array}$ & $\begin{array}{l}\text { Right breast } \\
\text { cancer }\end{array}$ & Aqueous & $\mathrm{G}(+) \ddagger \operatorname{cocci} 1+\neq \ddagger$ & $10^{4}-10^{6}$ \\
\hline & 2 & 62 & $\mathrm{~F}$ & OD & $\begin{array}{l}\text { Endophthalmitis } \\
\text { (exogenous) }\end{array}$ & $\begin{array}{l}\text { Right breast } \\
\text { cancer }\end{array}$ & Vitreous & $\mathrm{G}(+) \ddagger \operatorname{cocci} 1+$ & $10^{6}-10^{8}$ \\
\hline & 3 & 62 & $\mathrm{~F}$ & OD & $\begin{array}{l}\text { Endophthalmitis } \\
\text { (exogenous) }\end{array}$ & $\begin{array}{l}\text { Right breast } \\
\text { cancer }\end{array}$ & Aqueous & $\mathrm{N} / \mathrm{A}$ & $10^{6}-10^{8}$ \\
\hline & 4 & 47 & $\mathrm{~F}$ & OD & $\begin{array}{l}\text { Endophthalmitis } \\
\text { (endogenous) }\end{array}$ & $\begin{array}{l}\text { Sepsis, Right } \\
\text { breast cancer }\end{array}$ & Aqueous & $\begin{array}{l}\text { Aqueous: no } \\
\text { anaerobic } \\
\text { pathogen. }{ }^{+}\end{array}$ & $10^{6}-10^{8}$ \\
\hline & 5 & 73 & $\mathrm{~F}$ & OS * & $\begin{array}{l}\text { Endophthalmitis } \\
\text { (exogenous) }\end{array}$ & $\begin{array}{l}\text { Diabetes mellitus, } \\
\text { Hypertension }\end{array}$ & Vitreous & $\begin{array}{c}\text { Candida } \\
\text { parapsilosis } \\
\text { complex } 1+\end{array}$ & $>10^{8}$ \\
\hline Group $2 * *$ & 1 & 68 & $\mathrm{M}$ & OS & $\begin{array}{l}\text { Endophthalmitis } \\
\text { (exogenous) }\end{array}$ & $\begin{array}{l}\text { Hypertension, } \\
\text { ESRD with HD }\end{array}$ & Vitreous & No growth & 0 \\
\hline
\end{tabular}

* OD: oculus dexter, right eye; OS: oculus sinister, left eye; ${ }^{* *}$ Group2: After antibiotic treatment; $\ddagger_{\text {G denotes }}$ "Gram stain," G (+) Gram stain positive species, G (-) Gram stain negative species; 㧊 The semi-quantitative scoring of Gram stain was based on the number of bacteria per high-power $(\times 1000)$ oil immersion field: $0=$ no bacteria per field; $1+=$ less than one bacterium per field; $2+=1-5$ bacteria per field; $3+=6-30$ bacteria per field and $4+=$ more than 30 bacteria per field 1 [1]; + Although the final aqueous culture was negative, the patient's urine culture showed Enterococcus faecium $>100,000$, and the sputum culture showed $G(-)$ cocci $1+$. The final diagnosis made by ophthalmologists was endophthalmitis.

\subsubsection{MTT-PMS Assay of Human Urine Samples}

A total of 116 patients were included in the analysis (Table S1); most of them were females $(71 \%)$, with a mean age of 73.5 years. Urine culture results of $>10^{5} \mathrm{CFU} / \mathrm{mL}$ were considered positive and the threshold of our MTT-PMS assay was $>10^{5} \mathrm{CFU} / \mathrm{mL}$; however, sensitivity and specificity were $70 \%$ and $44.19 \%$, respectively (Table $2 a$ ). As the spectrophotometric analysis might have been affected by the hemoglobin or abnormal blood in the urine samples, we excluded samples with positive abnormal blood (OB, $n=59)$ and performed a subgroup analysis (OB group, Table 2). The sensitivity and specificity of the MTT-PMS assay in the subgroup were $100 \%$ and $44.00 \%$, respectively.

Table 2. Comparison of routine urine culture reports and 3-(4,5-dimethylthiazol-2-yl)-2,5diphenyltetrazolium bromide-phenazine methosulfate (MTT-PMS) assay results (cut-off value urine culture $>105 \mathrm{CFU} / \mathrm{mL}$ ).

\begin{tabular}{|c|c|c|c|c|}
\hline \multicolumn{5}{|c|}{ Comparison of Urine Culture Report $>10^{5} \mathrm{CFU} / \mathrm{mL}, n=116$} \\
\hline \multirow{5}{*}{ MTT-PMS assay $10^{5}(n)$} & & \multicolumn{3}{|c|}{ Urine Culture $>10^{5} \mathrm{CFU} / \mathrm{mL}(n)$} \\
\hline & & Positive & Negative & Total \\
\hline & Positive & 20 & 47 & 67 \\
\hline & Negative & 10 & 39 & 49 \\
\hline & Total & 30 & 86 & 116 \\
\hline \multirow{5}{*}{$\begin{array}{c}\text { Sensitivity } \\
66.67 \%\end{array}$} & Specificity & Accuracy & $\mathrm{PPV} *$ & NPV ** \\
\hline & $45.35 \%$ & $50.86 \%$ & $29.85 \%$ & $79.59 \%$ \\
\hline & \multicolumn{4}{|c|}{ Comparison of Urine Culture Report $>10^{5} \mathrm{CFU} / \mathrm{mL}, n=59, \mathrm{OB}^{-}{ }^{\dagger}$} \\
\hline & & Positive & Negative & Total \\
\hline & Positive & 9 & 28 & 37 \\
\hline \multirow[t]{2}{*}{ MTT-PMS assay $10^{5}(n)$} & Negative & 0 & 22 & 22 \\
\hline & Total & 9 & 50 & 59 \\
\hline Sensitivity & Specificity & Accuracy & PPV * & NPV ** \\
\hline $100.00 \%$ & $44.00 \%$ & $52.54 \%$ & $24.32 \%$ & $100.00 \%$ \\
\hline
\end{tabular}

* PPV: positive predictive value; ${ }^{* *} \mathrm{NPV}$ : negative predictive value; ${ }^{\dagger} \mathrm{OB}-:$ negative for abnormal blood; (a) Comparison of the MTT-PMS assay with urine culture results. The sensitivity, specificity, PPV, and NPV were $66.67 \%$, $45.35 \%, 29.85 \%$, and $79.59 \%$, respectively; (b) Comparison of the MTT-PMS assay results with urine culture reports in urine without abnormal blood. The sensitivity, specificity, PPV, and NPV were $100 \%, 44 \%, 24.32 \%$, and $100 \%$, respectively. 


\section{Discussion}

In this study, we modified the transitional MTT assay, extending its use to directly screen live bacteria in clinical human body fluid samples. MTT is a well-known colorimetric reagent for assessing metabolic activity within cells and has been utilized for a variety of experimental purposes, such as mycoplasma screening, detection of superoxide radicals, microbial viability, and growth estimation [26]. Although the exact mechanism of MTT reduction in bacteria is unclear, the MTT assay is widely utilized for detecting bacterial respiratory activity and viability $[26,32,33]$. The MTT assay traditionally takes several hours to complete [12]. We modified the traditional MTT assay to create an MTT-PMS assay, which introduces an additional electron-acceptor, with several optimized aspects including improved bacterial wall penetration and signal enhancement. Tris/EDTA solution was added to improve the bacterial wall penetration. The metal chelating agent, EDTA, can bind to divalent cations, such as $\mathrm{Ca}^{2+}$ and $\mathrm{Mg}^{2+}$, on the cell wall and increase cell permeability $[34,35]$. It can also specifically loosen the lipopolysaccharides of Gramnegative bacteria [36]. The $\mathrm{pH}$ was maintained at 8 to achieve maximal permeability. PMS solution was added to our MTT assay to accelerate the reaction between MTT and the dehydrogenase system present in the bacterial cytoplasmic membrane [37]. The inclusion of an intermediate electron acceptor facilitated the MTT reduction reaction [28,29]; $100 \mathrm{mM}$ $\mathrm{NaOH}(0.1 \mathrm{~N})$ was added to create an alkaline environment to accelerate the reaction and enhance the signal $[38,39]$. By combining each of these reagents and using them to augment our assay processes, the entire MTT-PMS assay for bacterial screening could be completed within $15 \mathrm{~min}$ [16]. The formazan crystals were stably dissolved in an alkaline solvent thus our solution was maintained at $\mathrm{pH} 8$ for stable dissolution [40]. The optimal wavelength of the formazan solution varies from $550 \mathrm{~nm}$ to $600 \mathrm{~nm}$, depending on the selected solvent $[26,40]$. In the MTT-PMS assay, our previous experience showed that the optimal wavelength was $595 \mathrm{~nm}$ for screening viable bacteria in water [16].

Using PBS as a standard condition, the standard curve was calculated using Hill's equation. The limit of detection was $10^{4}-10^{5.3}$ and the limit of quantification was $10^{5.3}-10^{6.5}$ (Figure 4e). These results are comparable to those generated by the current technology. Current bacterial detection systems detect pathogens through $\mathrm{CO}_{2}$ emission, based on the colorimetric detection of $\mathrm{pH}$ changes caused by the $\mathrm{CO}_{2}$ output of pathogenic microorganisms and have been successfully used in clinical settings since 1990 [41]. The reported threshold concentration for detection using these systems is approximately $10^{4} \mathrm{CFU} / \mathrm{mL}$ [11], and the processing time is approximately $10-15 \mathrm{~h}$. More importantly, to execute these techniques, a central laboratory and trained technicians are required [41,42]. For the broader application of the MTT-PMS assay, we developed a colorimetric MTT-PMS assay using ImageJ, an open-source image processing program, using a smartphone (iPhone XS, Apple). The semi-quantitative results produced by integrating smartphone-based analysis with MTT-PMS assay results allowed us to differentiate bacterial concentrations from $10^{4}$ to $10^{6} \mathrm{CFU}$ (Figure 5). The addition of smartphone technology may expand the utility of the MTT-PMS assay for bacterial screening.

This study further evaluated the clinical efficacy of the MTT-PMS assay for bacterial screening to determine whether it could provide semi-quantitative results when differentiating bacterial concentrations range from $10^{0} \mathrm{CFU} / \mathrm{mL}$ (sterile conditions) to $10^{8} \mathrm{CFU} / \mathrm{mL}$. Two types of clinical samples were selected for this study: intraocular fluid and urine samples. The intraocular fluid is a transparent and sterile fluid, similar to plasma [43]. Although intraocular sample collection is rare and laborious, low-protein-containing intraocular fluids represent a relatively simple situation for analysis. In contrast, urinary tract infections are highly prevalent diseases and bacteria-contaminated urine samples are more accessible [44], however, urine samples are challenging because they are $90 \%$ water and may include other minor organic or inorganic materials depending on host's metabolic conditions [45].

Intraocular fluid is sterile, but microorganisms, such as bacteria or fungi, may infect the eye and cause endophthalmitis, an acute vision-threatening condition. Delayed diagnosis or 
inappropriate treatment of such diseases may result in catastrophic consequences, including severely impaired visual acuity within 12-24 h [46-48]. Endophthalmitis is diagnosed based on either clinical judgment or through microbiological culturing of samples obtained through vitreous or aqueous aspiration [49]. Due to endophthalmitis being rare and sample aspiration being an invasive procedure, only six intraocular fluid samples were obtained for this study. We compared the correlation between the MTT-PMS assay and a definitive diagnosis (either a culturing test or clinical judgment) (Table 1). Five samples in Group 1 were collected before the antibiotic treatment and all the samples produced a positive colorimetric MTT-PMS reaction. These results were consistent with a definitive diagnosis of endophthalmitis. Positive MTT-PMS assay results indicated the presence of microorganisms in the aqueous sample. Microorganism culture might have been hindered by the presence of fastidious organisms, prior antimicrobial exposure, or bacterial concentrations that were too low for culture being the outcome [50,51]. The sample in Group 2 was collected after intra-vitreous antibiotic administration, and therefore, neither the MTT-PMS assay nor the respective vitreous culture was positive. These consistent MTT-PMS assays and vitreous culture results imply that there were no live microorganisms in the sample.

UTI is a common infectious disease with a 50-60\% lifetime incidence among adult women and a $10 \%$ incidence in the entire population [44]. Moreover, UTI accounts for the second most common nosocomial infection and can cause sepsis or septic shock if left untreated [52]. The diagnosis of UTI is based on clinical presentation and bacteriuria confirmed by a positive urine culture result. Bacteriuria was defined as a bacterial culture of $>10^{5} \mathrm{CFU} / \mathrm{mL}$. Although urine culture is the gold standard for bacteriuria diagnosis, it requires several days [52]. Therefore, we introduced an MTT-PMS assay approach for the real-time screening of bacterial presence in urine samples. Our MTT-PMS assay demonstrated a negative predictive value (NPV) of 79.59\% (Table 2). The exact mechanism remains unclear, but previous studies have reported that the presence of heme might interfere with the spectral absorption and the redox reaction of the MTT-PMS assay, causing either false-positive or false-negative results [53-55]. Hence, we excluded urine samples that contained abnormal blood. The results showed that the NPV of the MTT-PMS assay was $100 \%$ when urine samples with abnormal blood were excluded (Table 2). With its high sensitivity and high NPV, the MTT-PMS assay may be a useful bacteriuria screening tool for urine samples that do not contain abnormal blood. Negative MTT-PMS results indicated a low risk of bacteriuria.

A point-of-care testing device should be easy-to-use, accurate, cost-efficient, rapid, and require only a non-technical user to operate, detecting targeted objects with limited infrastructure [56]. Our previous study reported that the MTT-PMS assay is a rapid detection tool for viable bacteria in water [16]. This study of the MTT-PMS assay in clinical samples demonstrated high sensitivity for detecting microorganisms in both intraocular fluid and urine. Compared to contemporary bacterial detection methods, the spread-plate or multi-tube fermentation requires a few days to obtain the results and the real-time quantitative PCR or ELISA requires several hours [16,57-59]. In contrast, this MTT-PMS assay requires only a small sample size $(30 \mu \mathrm{L})$, is inexpensive (approximately USD 1 per test), and requires only $15 \mathrm{~min}$ to obtain semi-quantitative results [16].

A point-of-care testing device can only make a difference if this technique can be commercialized. For commercial purposes, this technique should be integrated with disposable or microfluidic platforms, implement surface-bound detect techniques, and rely on open-source hardware or software [56]. Using a colorimetric device, we can evaluate the results of the MTT-PMS assay easily and accurately [16]. In addition to being readable using a microplate reader, this study further demonstrates the efficacy of a semi-quantitative, colorimetric analysis of the MTT-PMS assay using an open-source application, ImageJ (Figure 4). We previously successfully integrated the MTT assay into a low-cost, laboratoryfree, easy-to-use, paper-based device to evaluate porcine sperm motility. The MTT assay was embedded on a designed paper-based device, and the colorimetric results could be evaluated via a smartphone application [60-63]. The integration of this technique into 
a paper-based device that can be analyzed with a smartphone makes it highly portable and accessible for use in local clinics and communities. The collective characteristics of the MTT-PMS assay and associated point-of-care integration indicates that it might be a useful "rule-out" tool for pathogen presence screening that could be used before routine culture techniques.

This study evaluated a specific and novel diagnostic application of the MTT-PMS assay, but it has several limitations. First, the sample size was limited because of the low prevalence of intraocular infection and the highly invasive nature of intraocular fluid aspiration. Moreover, because the contents of human urine are heterogeneous and variable according to patient metabolic conditions, it was challenging to develop a "standard" condition to calculate the limit of detection in the urine sample. Furthermore, the interference of heme or hemoglobin hindered the utility of the MTT-PMS assay. Additional studies are required to eliminate heme interference and broaden the utility of the MTT-PMS assay, especially for use with samples containing blood. Finally, the limit of detection of the MTT-PMS assay was only $10^{4}-10^{5.3}$, a value that should be improved by further optimizing the elements of the MTT-PMS assay.

In conclusion, our study revealed that the MTT-PMS assay has several potential uses and advantages:

1. It could be used as a "rule-out" test for infectious diseases screening. A negative MTT-PMS assay result may indicate a low possibility of "live" microorganism presence $[26,64]$. Using screening methods before conventional microorganism culture may reduce the potential risk of stratification of febrile patients and guide initial treatment [23].

2. Rapid results. By adding reagents to improve bacterial wall penetration, facilitating the provision of an additional electron acceptor, and enhancing the resulting signal, this MTT-PMS assay has been optimized to quickly detect the presence of microorganisms and provide real-time semi-quantitative screening of infectious diseases within 15 min.

3. Semi-quantitative readout. This process provides rapid and semi-quantitative information regarding the presence of microorganisms without sophisticated equipment or trained technicians.

4. Potential POCT device. This MTT-PMS assay may be integrated into a paper-based device and colorimetric analysis can be performed using a smartphone color-recognition application [16,60-63]. Moreover, the MTT-PMS assay can further be embedded into a disposable paper-based device and evaluated with a smartphone or an open-source application (Image J). These features indicate the MTT-PMS assay has the potential to be commercialized.

\section{Conclusions}

Infectious diseases impose a huge burden on both healthcare and socio-economic systems; thus, real-time accurate diagnostic methods are required $[1,4,25]$. The MTT-PMS assay provides a low-cost, rapid, and easy-to-use approach for detecting the presence of "live" microorganisms [65], and therefore possess the potential to be commercialized. It can be incorporated into conventional microorganism culture methods as a rapid infectious disease screening tool. Although we found a high NPV for the urinary MTT-PMS assay, it is unclear how abnormal blood interferes with the MTT-PMS assay. Further investigation may reveal the broader applicability of MTT-PMS assay-based microorganism detection.

Supplementary Materials: The supplementary material is available online at https:/ /www.mdpi. com/article/10.3390/diagnostics12010046/s1. Details of the reagents, equipment, bacterial preparation, and establishment of standard curves are shown in Table S1. Characteristics and results of patients with urinary tract infections are also shown in the Supplementary Materials. 


\begin{abstract}
Author Contributions: Conceptualization, Y.-C.W., Y.-T.L., C.-F.S. and C.-M.C.; methodology, Y.-T.L., C.-H.C. and P.-T.Y.; software, W.-T.L. and Y.-H.L.; validation, Y.-T.T., W.-T.L., Y.-H.L. and C.-M.C.; formal analysis, C.-H.C., Y.-T.T. and Y.-H.L.; investigation, C.-H.C. and Y.-T.T.; clinical samples collection and ethical institutional review board approval, C.-H.C., P.-T.Y. and C.-M.C.; data curation, C.-H.C., Y.-T.T. and Y.-H.L.; writing-original draft preparation, C.-H.C. and Y.-T.T.; writing—review and editing, C.-H.C. and C.-M.C.; visualization, C.-H.C. and Y.-T.T.; supervision, Y.-T.L., C.-F.S. and C.-M.C.; project administration, C.-M.C.; funding acquisition, C.-H.C., C.-F.S. and C.-M.C. All authors have read and agreed to the published version of the manuscript.
\end{abstract}

Funding: This study was funded by research grants from the Ministry of Science and Technology, Taiwan (MOST 107-2628-E-007-001-MY3 and MOST 110-2221-E-007-073-MY2 to C.-M.C., MOST 109-2222-E-075-001 to C.-H.C., and MOST 109-2635-B-006-004 and MOST 110-2923-B-006-001-MY4 to C.-F.S.) and the Frontier Research Center on Fundamental and Applied Sciences of Matters from the Featured Areas Research Center Program within the framework of the Higher Education Sprout Project by the Ministry of Education (MOE 107QR001I5), Taiwan.

Institutional Review Board Statement: Approvals were obtained from the Institutional Review Board (IRB) of the National Taiwan University Hospital (IRB number 1083707256) and IRB of Taipei Veterans General Hospital (IRB, TPEVGH 2019-10-001B)

Informed Consent Statement: Informed consent was obtained from all subjects involved in the study.

Data Availability Statement: The datasets of this research are available on request to the corresponding author.

Conflicts of Interest: The authors declare no conflict of interest.

\title{
References
}

1. Rudd, K.E.; Johnson, S.C.; Agesa, K.M.; Shackelford, K.A.; Tsoi, D.; Kievlan, D.R.; Colombara, D.V.; Ikuta, K.S.; Kissoon, N.; Finfer, S.; et al. Global, regional, and national sepsis incidence and mortality, 1990-2017: Analysis for the Global Burden of Disease Study. Lancet 2020, 395, 200-211. [CrossRef]

2. Mitsakakis, K.; D'Acremont, V.; Hin, S.; von Stetten, F.; Zengerle, R. Diagnostic tools for tackling febrile illness and enhancing patient management. Microelectron. Eng. 2018, 201, 26-59. [CrossRef]

3. El Bcheraoui, C.; Mokdad, A.H.; Dwyer-Lindgren, L.; Bertozzi-Villa, A.; Stubbs, R.W.; Morozoff, C.; Shirude, S.; Naghavi, M.; Murray, C.J.L. Trends and Patterns of Differences in Infectious Disease Mortality Among US Counties, 1980-2014. JAMA J. Am. Med. Assoc. 2018, 319, 1248-1260. [CrossRef]

4. Vila, J.; Gómez, M.D.; Salavert, M.; Bosch, J. Métodos de diagnóstico rápido en microbiología clínica: Necesidades clínicas. Enferm. Infecc. Microbiol. Clín. 2017, 35, 41-46. [CrossRef] [PubMed]

5. $\quad$ Reali, S.; Najib, E.Y.; Balázs, K.E.T.; Tan, A.C.H.; Váradi, L.; Hibbs, D.E.; Groundwater, P.W. Novel diagnostics for point-of-care bacterial detection and identification. RSC Adv. 2019, 9, 21486-21497. [CrossRef]

6. Craig, J.; Williams, G.J.; Jones, M.; Codarini, M.; Macaskill, P.; Hayen, A.; Irwig, L.; Fitzgerald, D.A.; Isaacs, D.; McCaskill, M. The accuracy of clinical symptoms and signs for the diagnosis of serious bacterial infection in young febrile children: Prospective cohort study of 15781 febrile illnesses. BMJ 2010, 340, c1594. [CrossRef]

7. Buck, C.; Bundschu, J.; Bartmann, P.; Pohlandt, F.; Gallati, H. Interleukin-6: A Sensitive Parameter for the Early Diagnosis of Neonatal Bacterial Infection. Pediatrics 1994, 93, 54-58. [CrossRef]

8. Virkki, R.; Juven, T.; Rikalainen, H.; Svedström, E.; Mertsola, J.; Ruuskanen, O. Differentiation of bacterial and viral pneumonia in children. Thorax 2002, 57, 438-441. [CrossRef] [PubMed]

9. Multani, A.; Allard, L.S.; Wangjam, T.; Sica, R.A.; Epstein, D.J.; Rezvani, A.R.; Ho, R.Y. Missed diagnosis and misdiagnosis of infectious diseases in hematopoietic cell transplant recipients: An autopsy study. Blood Adv. 2019, 3, 3602-3612. [CrossRef] [PubMed]

10. Reddy, B.; Hassan, U.; Seymour, C.; Angus, D.C.; Isbell, T.S.; White, K.; Weir, W.; Yeh, L.; Vincent, A.; Bashir, R. Point-of-care sensors for the management of sepsis. Nat. Biomed. Eng. 2018, 2, 640-648. [CrossRef]

11. Puttaswamy, S.; Lee, B.D.; Sengupta, S. Novel Electrical Method for Early Detection of Viable Bacteria in Blood Cultures. J. Clin. Microbiol. 2011, 49, 2286-2289. [CrossRef]

12. Lagier, J.-C.; Edouard, S.; Pagnier, I.; Mediannikov, O.; Drancourt, M.; Raoult, D. Current and Past Strategies for Bacterial Culture in Clinical Microbiology. Clin. Microbiol. Rev. 2015, 28, 208-236. [CrossRef] [PubMed]

13. Kang, C.-I.; Kim, J.; Park, D.W.; Kim, B.-N.; Ha, U.-S.; Lee, S.-J.; Yeo, J.; Min, S.K.; Lee, H.; Wie, S.-H. Clinical Practice Guidelines for the Antibiotic Treatment of Community-Acquired Urinary Tract Infections. Infect. Chemother. 2018, 50, 67-100. [CrossRef]

14. Pfister, H.W.; Brouwer, M.C.; Esposito, S.; Dzupova, O.; Van De Beek, D.; Leib, S.; Pagliano, P.; Cabellos, C.; Sipahi, O.R.; Mourvillier, B.; et al. ESCMID guideline: Diagnosis and treatment of acute bacterial meningitis. Clin. Microbiol. Infect. 2016, 22, S37-S62. [CrossRef] 
15. Sanders, E.R. Aseptic Laboratory Techniques: Plating Methods. J. Vis. Exp. 2012, 63, e3064. [CrossRef]

16. Liao, Y.-H.; Muthuramalingam, K.; Tung, K.-H.; Chuan, H.-H.; Liang, K.-Y.; Hsu, C.-P.; Cheng, C.-M. Portable Device for Quick Detection of Viable Bacteria in Water. Micromachines 2020, 11, 1079. [CrossRef] [PubMed]

17. Carbonnelle, E.; Mesquita, C.; Bille, E.; Day, N.; Dauphin, B.; Beretti, J.-L.; Ferroni, A.; Gutmann, L.; Nassif, X. MALDI-TOF mass spectrometry tools for bacterial identification in clinical microbiology laboratory. Clin. Biochem. 2011, 44, 104-109. [CrossRef]

18. Järvinen, A.-K.; Laakso, S.; Piiparinen, P.; Aittakorpi, A.; Lindfors, M.; Huopaniemi, L.; Piiparinen, H.; Mäki, M. Rapid identification of bacterial pathogens using a PCR- and microarray-based assay. BMC Microbiol. 2009, 9, 161. [CrossRef] [PubMed]

19. Itoh, S.; Kariya, M.; Nagano, K.; Yokoyama, S.-I.; Fukao, T.; Yamazaki, Y.; Mori, H. New Rapid Enzyme-Linked Immunosorbent Assay to Detect Antibodies against Bacterial Surface Antigens Using Filtration Plates. Biol. Pharm. Bull. 2002, 25, 986-990. [CrossRef]

20. Wang, S.; Lifson, M.A.; Inci, F.; Liang, L.-G.; Sheng, Y.-F.; Demirci, U. Advances in addressing technical challenges of point-of-care diagnostics in resource-limited settings. Expert Rev. Mol. Diagn. 2016, 16, 449-459. [CrossRef]

21. Santibañez, S.; Bellis, K.S.; Bay, A.; Chung, C.L.; Bradley, K.; Gibson, D.; Shultz, A. Strengthening Rural States' Capacity to Prepare for and Respond to Emerging Infectious Diseases, 2013-2015. South. Med. J. 2019, 112, 101-105. [CrossRef] [PubMed]

22. Sokhna, C.; Mediannikov, O.; Fenollar, F.; Bassene, H.; Diatta, G.; Tall, A.; Trape, J.-F.; Drancourt, M.; Raoult, D. Point-of-Care Laboratory of Pathogen Diagnosis in Rural Senegal. PLoS Neglected Trop. Dis. 2013, 7, e1999. [CrossRef] [PubMed]

23. Oeschger, T.; McCloskey, D.; Kopparthy, V.; Singh, A.; Erickson, D. Point of care technologies for sepsis diagnosis and treatment. Lab Chip 2019, 19, 728-737. [CrossRef]

24. Drain, P.; Hyle, E.P.; Noubary, F.; Freedberg, K.A.; Wilson, D.; Bishai, W.R.; Rodriguez, W.; Bassett, I.V. Diagnostic point-of-care tests in resource-limited settings. Lancet Infect. Dis. 2014, 14, 239-249. [CrossRef]

25. Vashist, S.K. Point-of-Care Diagnostics: Recent Advances and Trends. Biosensors 2017, 7, 62. [CrossRef]

26. Grela, E.; Kozłowska, J.; Grabowiecka, A. Current methodology of MTT assay in bacteria-A review. Acta Histochem. 2018, 120, 303-311. [CrossRef]

27. Braissant, O.; Astasov-Frauenhoffer, M.; Waltimo, T.; Bonkat, G. A Review of Methods to Determine Viability, Vitality, and Metabolic Rates in Microbiology. Front. Microbiol. 2020, 11, 547458. [CrossRef]

28. Muelas-Serrano, S.; Nogal-Ruiz, J.J.; Gómez-Barrio, A. Setting of a colorimetric method to determine the viability of Trypanosoma cruzi epimastigotes. Parasitol. Res. 2000, 86, 999-1002. [CrossRef]

29. Cedillo-Rivera, R.; Ramírez, A.; Muñoz, O. A rapid colorimetric assay with the tetrazolium salt MTT and phenazine methosulfate (PMS) for viability of Entamoeba histolytica. Arch. Med. Res. 1992, 23, 59-61.

30. Silverthorn, D.U.; Ober, W.C.; Garrison, C.W.; Silverthorn, A.C.; Johnson, B.R. Human Physiology: An Integrated Approach; Benjamin-Cummings, Pearson: San Francisco, CA, USA, 2010.

31. Rasband, W.S. ImageJ; Version 1.53d; U.S. National Institutes of Health: Bethesda, MD, USA, 1997-2021. Available online: https:/ /imagej.nih.gov/ij/ (accessed on 25 March 2021).

32. Denizot, F.; Lang, R. Rapid colorimetric assay for cell growth and survival. Modifications to the tetrazolium dye procedure giving improved sensitivity and reliability. J. Immunol. Methods 1986, 89, 271-277. [CrossRef]

33. Tsukatani, T.; Suenaga, H.; Higuchi, T.; Akao, T.; Ishiyama, M.; Ezoe, K.; Matsumoto, K. Colorimetric cell proliferation assay for microorganisms in microtiter plate using water-soluble tetrazolium salts. J. Microbiol. Methods 2008, 75, 109-116. [CrossRef]

34. Finnegan, S.; Percival, S. EDTA: An Antimicrobial and Antibiofilm Agent for Use in Wound Care. Adv. Wound Care 2015, 4, 415-421. [CrossRef] [PubMed]

35. Thomas, K.J.; Rice, C.V. Revised model of calcium and magnesium binding to the bacterial cell wall. BioMetals 2014, 27, 1361-1370. [CrossRef]

36. Leive, L. The barrier function of the gram-negative envelope. Ann. N. Y. Acad. Sci. 1974, 235, 109-129. [CrossRef] [PubMed]

37. Schnaitman, C.A. Protein Composition of the Cell Wall and Cytoplasmic Membrane of Escherichia coli. J. Bacteriol. 1970, 104, 890-901. [CrossRef]

38. Kuan, C.-M.; York, R.L.; Cheng, C.-M. Lignocellulose-based analytical devices: Bamboo as an analytical platform for chemical detection. Sci. Rep. 2016, 5, 18570. [CrossRef]

39. Estrela, C.; Estrela, C.; Barbin, E.L.; Spanó, J.C.E.; Marchesan, M.; Pecora, J.D. Mechanism of action of sodium hypochlorite. Braz. Dent. J. 2002, 13, 113-117. [CrossRef] [PubMed]

40. Wang, H.; Wang, F.; Tao, X.; Cheng, H. Ammonia-containing dimethyl sulfoxide: An improved solvent for the dissolution of formazan crystals in the 3-(4,5-dimethylthiazol-2-yl)-2,5-diphenyl tetrazolium bromide (MTT) assay. Anal. Biochem. 2012, 421, 324-326. [CrossRef] [PubMed]

41. Jacobs, M.R.; Mazzulli, T.; Hazen, K.C.; Good, C.E.; Abdelhamed, A.M.; Lo, P.; Shum, B.; Roman, K.P.; Robinson, D.C. Multicenter clinical evaluation of BacT/Alert Virtuo blood culture system. J. Clin. Microbiol. 2017, 55, 2413-2421. [CrossRef]

42. Kim, S.C.; Lee, S.; Kim, S.; Cho, O.-H.; Park, H.; Yu, S.-M. Comparison of Clinical Performance Between BacT/Alert Virtuo and BacT / Alert 3D Blood Culture Systems. Ann. Lab. Med. 2019, 39, 278-283. [CrossRef]

43. Silverthorn, D.U. Human Physiology: An Integrated Approach; E-Book; Pearson Higher: San Francisco, CA, USA, 2018.

44. Medina, M.; Castillo-Pino, E. An introduction to the epidemiology and burden of urinary tract infections. Ther. Adv. Urol. 2019, 11, 1756287219832172. [CrossRef] [PubMed] 
45. Rose, C.; Parker, A.; Jefferson, B.; Cartmell, E. The Characterization of Feces and Urine: A Review of the Literature to Inform Advanced Treatment Technology. Crit. Rev. Environ. Sci. Technol. 2015, 45, 1827-1879. [CrossRef]

46. Novosad, B.D.; Callegan, M.C. Severe bacterial endophthalmitis: Towards improving clinical outcomes. Expert Rev. Ophthalmol. 2010, 5, 689-698. [CrossRef]

47. Al-Omran, A.M.; Abboud, E.B.; Abu El-Asrar, A.M. Microbiologic spectrum and visual outcome of posttraumatic endophthalmitis Retina 2007, 27, 236-242. [CrossRef] [PubMed]

48. Jackson, T.; Eykyn, S.J.; Graham, E.M.; Stanford, M.R. Endogenous bacterial endophthalmitis: A 17-year prospective series and review of 267 reported cases. Surv. Ophthalmol. 2003, 48, 403-423. [CrossRef]

49. Durand, M.L.; Miller, J.W.; Young, L.H. Endophthalmitis; Springer: Berlin/Heidelberg, Germany, 2016.

50. Deshmukh, D.; Joseph, J.; Chakrabarti, M.; Sharma, S.; Jayasudha, R.; Sama, K.C.; Sontam, B.; Tyagi, M.; Narayanan, R.; Shivaji, S. New insights into culture negative endophthalmitis by unbiased next generation sequencing. Sci. Rep. 2019, 9, 844. [CrossRef] [PubMed]

51. Malekzadeh, D.; Osmon, D.R.; Lahr, B.D.; Hanssen, A.D.; Berbari, E.F. Prior Use of Antimicrobial Therapy is a Risk Factor for Culture-negative Prosthetic Joint Infection. Clin. Orthop. Relat. Res. 2010, 468, 2039-2045. [CrossRef] [PubMed]

52. Mambatta, A.K.; Rashme, V.L.; Menon, S.; Jayarajan, J.; Harini, S.; Kuppusamy, J. Reliability of dipstick assay in predicting urinary tract infection. J. Fam. Med. Prim. Care 2015, 4, 265-268. [CrossRef]

53. Stepanenko, A.; Dmitrenko, V. Pitfalls of the MTT assay: Direct and off-target effects of inhibitors can result in over/underestimation of cell viability. Gene 2015, 574, 193-203. [CrossRef]

54. Postnikova, G.B.; Shekhovtsova, E.A. Hemoglobin and myoglobin as reducing agents in biological systems. Redox reactions of globins with copper and iron salts and complexes. Biochemistry (Moscow) 2016, 81, 1735-1753. [CrossRef]

55. Ono, J.; Yoshimura, H. Prevention of hemoglobin interference on the formazan reaction. Clin. Chim. Acta 2008, 390, 115-121. [CrossRef]

56. Nguyen, T.; Chidambara, V.A.; Andreasen, S.Z.; Golabi, M.; Huynh, V.N.; Linh, Q.T.; Bang, D.D.; Wolff, A. Point-of-care devices for pathogen detections: The three most important factors to realise towards commercialization. TrAC Trends Anal. Chem. 2020, 131, 116004. [CrossRef]

57. Kralik, P.; Slana, I.; Kralova, A.; Babak, V.; Whitlock, R.H.; Pavlik, I. Development of a predictive model for detection of Mycobacterium avium subsp. paratuberculosis in faeces by quantitative real time PCR. Vet. Microbiol. 2011, 149, 133-138. [CrossRef] [PubMed]

58. Kralik, P.; Ricchi, M. A Basic Guide to Real Time PCR in Microbial Diagnostics: Definitions, Parameters, and Everything. Front. Microbiol. 2017, 8, 108. [CrossRef]

59. Kong, D.; Liu, L.; Xing, C.; Kuang, H.; Xu, C. Sensitive and highly specific detection of Cronobacter sakazakii based on monoclonal sandwich ELISA. Food Agric. Immunol. 2015, 26, 566-576. [CrossRef]

60. Matsuura, K.; Wang, W.-H.; Ching, A.; Chen, Y.; Cheng, C.-M. Paper-Based Resazurin Assay of Inhibitor-Treated Porcine Sperm. Micromachines 2019, 10, 495. [CrossRef] [PubMed]

61. Matsuura, K.; Huang, H.-W.; Chen, M.-C.; Chen, Y.; Cheng, C.-M. Relationship between Porcine Sperm Motility and Sperm Enzymatic Activity using Paper-based Devices. Sci. Rep. 2017, 7, srep46213. [CrossRef]

62. Lin, S.-C.; Hsu, M.-Y.; Kuan, C.-M.; Wang, H.-K.; Chang, C.-L.; Tseng, F.-G.; Cheng, C.-M. Cotton-based Diagnostic Devices. Sci. Rep. 2015, 4, 6976. [CrossRef]

63. Tsao, Y.; Yang, C.; Wen, Y.; Chang, T.; Matsuura, K.; Chen, Y.; Cheng, C. Point-of-care semen analysis of patients with infertility via smartphone and colorimetric paper-based diagnostic device. Bioeng. Transl. Med. 2021, 6, 10176. [CrossRef]

64. Wang, H.; Cheng, H.; Wang, F.; Wei, D.; Wang, X. An improved 3-(4,5-dimethylthiazol-2-yl)-2,5-diphenyl tetrazolium bromide (MTT) reduction assay for evaluating the viability of Escherichia coli cells. J. Microbiol. Methods 2010, 82, 330-333. [CrossRef]

65. Benov, L. Effect of growth media on the MTT colorimetric assay in bacteria. PLoS ONE 2019, 14, e0219713. [CrossRef] [PubMed] 